\title{
Misbehavior of Pedagogical Students in Classroom: A Case Study of Can Tho University in Viet Nam
}

\author{
Luong Tran \\ Department of Psychology in Education, School of Education, Can Tho University, Viet Nam \\ Received February 12, 2020; Revised May 15, 2020; Accepted May 20, 2020
}

Copyright $(02020$ by authors, all rights reserved. Authors agree that this article remains permanently open access under the terms of the Creative Commons Attribution License 4.0 International License

\begin{abstract}
Misbehavior is one of the components related to students' personalities. The previous studies have confirmed that misbehaviors of students in the classroom affect negatively in teaching and learning process and personalities of pedagogical students. The level of misbehaviors of pedagogical students in the classroom at Can Tho University in Vietnam has not been insufficiently researched to remedy this situation. This study was conducted to seek to answer the question: is the occurrence of misbehaviors among students in Can Tho University, Viet Nam related to their gender, majors and school year? The questionnaires designed were delivered to 232 pedagogical students in Can Tho University, Viet Nam. The SPSS for Windows was used to code via, and analyze the data collected by Percent, Frequencies, Mean, Std. Deviation T-Test, and Spearman Correlation. The results of this study showed that pedagogical students had various kinds of misbehaviors conducted in the classroom. There were no correlations and significant differences between mean scores of misbehaviors of pedagogical students regarding gender and school year. Otherwise, correlations and significant differences between mean scores of misbehaviors of pedagogical students regarding majors were found. These findings help to put forward a suggestion that those who work in training and education need to pay attention to the characteristics of students' majors in the process of adjusting misbehaviors for students.
\end{abstract}

Keywords Misbehavior, Students, Teacher Training

\section{Introduction}

No single definition exists for student misbehavior, although the term is conceptualized consistently as behaviors that disrupt the teaching-learning process or interfere with the orderly operation of the classroom (Finn, J. D., Fish, R. M., \& Scott, L. A, 2008; Houghton, S., Wheldall, K., \& Merrett, F, 1988; Thompson, 2009). Misbehaviors (problem behaviors) are behaviors involving rule-breaking, violating the implicit norms or expectations, being inappropriate in the classroom settings and upsetting teaching and learning (Rachel C.F.Sun \& Daniel T.L.Shek, 2012), unruly behavior which upsets classroom order and hampers teaching and learning (Houghton F, Wheldall K\& Merrett F, 1998; Little E, 2005; Thompson B, 2009), any behavior that undermines the teacher's ability to establish and maintain effective learning experience in the classroom from simple non-compliance (e.g., not paying attention) to overt disruptive behavior (e.g., throwing a missile across the room and serious misbehavior such as direct disobedience, physical aggression or damage (Kyriacou 1997).

Misbehavior includes skipping or being late to class, disrupting instruction (e.g., speaking out of turn, swearing, getting out of seat without permission), verbal abuse or disrespect toward teachers, noncompliance (i.e., failure to follow directions), off-task behavior, bullying, harassment, and gang activity (Bru, E., Stephens, P., \& Torsheim, T, 2002; Fernet et al., 2011; Finn et al., 2008; Robers et al., 2012), seeking unallowed assistance, internet slacking, aggressiveness, and lack of communication talking ( $\mathrm{Li} \mathrm{Li}$ \& Scott Titsworth, 2015), bullying, fighting, teasing, stealing, truancy, disobedience, and insubordination, lying, plagiarism, lateness, rudeness, destructiveness, drug or alcohol addiction (G. N. Tiwari \& Heena Panwar, non-attentiveness, daydreaming, and idleness and the disrespecting teachers in terms of disobedience and rudeness, followed by talking out of turn and verbal aggression was the most unacceptable problem behaviour. Rachel C. F. Sun1 \& Daniel T. L. Shek (2012)

Behavior problems (Misbehaviors) have become progressively more important to schools (Long, 2000). Misbehaviors of pedagogical student in classroom is a very serious problem because it not only affects negatively the 
teaching and learning (Rachel C. F. Sun \& Daniel T. L. Shek, 2012; DG. N. Tiwari \& Heena Panwar 2014), teacher's mental health at stake, students' learning outcomes (Wheldall, 1991) such as the level of misbehavior in a given classroom affects performance on a mathematics evaluation (Alex Hwung, 2016) but it also affects personality of pedagogical student who will be teachers in the future. Student misbehavior interferes with their teaching activities (Robers, Zhang, Truman, \& Snyder, 2012). Student misbehavior was the most salient stressor related to teacher burnout (McCormick \& Barnett, 2011). Student misbehavior is one of the factors related most strongly to teacher burnout (Burke, Greenglass, \& Schwarzer, 1996; Friedman, 1995). For many teachers, dealing with student misbehavior in the classroom takes up a considerable proportion of teaching time, which in turn affects the quality of the student's learning experience (Xinrui Yuan, 2012), and misbehavior disturbed the teaching and learning process and violated the values of respect, conformity, and obedience in the teacher-student relationship within the classroom (Rachel C. F. Sun \& Daniel T. L. Shek, 2012).

The previous studies found out there was a correlation between the misbehavior of students with teacher well-being and enthusiasm (Karen Aldrupa et al, 2018), teachers' teaching field, teacher seniority, educational background of teachers, and many students in the classroom in the term in teachers' perceptions of student misbehavior (Gülay Dalgıç \& Güzide Bayhan, 2014), parenting styles (Hoshiar Sadiq Sangawi et al, 2015), the dimension of teacher burnout, teacher emotional exhaustion, depersonalization, and personal accomplishment (Ariel M. Aloeet al (2014), generation immigrants (Ewert. S, 2009), teachers' confidence, the use of school-based support, the use of non-physical punishment and referral of the student to other school personnel and the need for positively-focused and teacher-focused information (Martin et al, 1999), different cultural and educational contexts (Abbas Türnüklü \& Maurice Galton, 2001), the students, the teacher, and the society (Xinrui Yuan, 2012), aggression by teachers (Lewis, Romi, Qui \& Katz, 2005). Alice M. Buchanan, Vanessa Hinton (2018) demonstrated that the significant differences in students' total behavior marks before and after receiving instruction with PBIS. Significant differences were found for three of the five rules. Van Dat Tran (2016) indicated that coping styles mediated the relationship between teachers' concerns about student misbehavior and their use of classroom management techniques and teachers who use passive avoidant strategies employ more aggression and punishment techniques towards student misbehavior.

It is not clear whether the status misbehavior of pedagogical student at Can Tho University in Vietnam and the correlation and significant differences between the mean score of misbehavior of pedagogical students in term male and female, natural science and social science have not been studied yet, as we know. Therefore, this research seeks to answer the question; is the occurrence of misbehavior of pedagogical students at Can Tho University in Vietnam related to their gender, majors and school year status?

\section{Materials and Method}

To find out the occurrence of pedagogical students' misbehaviors in Can Tho University in Vietnam and the correlation and significant differences between the mean score of misbehavior of pedagogical students in term male and female, natural science and social science, the research question and hypothesis are defined as follows:

\subsection{Research Question and Hypothesis}

What is the occurrence of pedagogical students' misbehaviors in Can Tho University, Viet Nam? Is the occurrence of misbehaviors among pedagogical students in Can Tho University, Viet Nam related to their gender, majors, and school year status?

$\mathrm{H}_{01}$ : Pedagogical students have no various kinds of misbehaviors conducted in the classroom.

$\mathrm{H}_{02}$ : There were no correlations and significant differences between mean scores of misbehaviors of pedagogical students regarding male and female.

$\mathrm{H}_{03}$ : There were nocorrelations and significant differences between mean scores of misbehaviors of pedagogical students regarding natural science and social science.

$\mathrm{H}_{04}$ : There were no correlations and significant differences between mean scores of misbehaviors of pedagogical students regarding 2 nd year and 3 rd year.

\subsection{Survey Participants}

232 pedagogical students in Can Tho University, Viet Nam The population were randomly chosen to survey including: 156 male students $(67,29 \%)$, and 76 females $(32,8 \%) ; 108$ students majored in natural science $(46,6 \%)$, and 124 students majored in social science $(53,4 \%) ; 143$ 2nd year students $(61,6 \%), 893$ rd year students $(38,4 \%)$. The survey was carried out from June to September 2019.

\subsection{Study Design}

The questionnaire is designed by Vietnamese including an introduction of survey objective and the instruction on how to answer the questions; The objective information, including the questions on participants' fundamental information, listing as gender, school year, and major which he/she is studying; Survey content includes question system which collects data related to the current misbehavior of students in the classroom. The question 
system is comprised of 8 questions (items) that concentrate on the misbehavior of students in the classroom. These items are defined which based on the concepts of misbehavior in the classroom given by Finn, J. D., Fish, R. M., \& Scott, L. A (2008); Houghton, S., Wheldall, K., \& Merrett, F (1988); Thompson (2009); Rachel C. F. Sun \& Daniel T. L. Shek (2012); Houghton F, Wheldall K\& Merrett F (1998); Little E (2005); Thompson B (2009); (Kyriacou 1997) as above. Responses for students to answer are designed based on 5 levels (Likert-scale) (Croasmun \& Ostrom, 2011). The reliability statistics of the questionnaire with Cronbach's Alpha 0.74 for 8 items.

\subsection{Data Analysis}

Students' answers were assessed based on 05 points of Likert scale (James T. Croasmun \& Lee Ostrom, 2011) and coded via as follows: Scale $1=1$, Scale $2=2$, Scale $3=3$. Scale $4=4$, Scale $5=5$. Distance Value $=($ Maximum Minimum) $/ \mathrm{n}=(5-1) / 5=0.8$. Therefore, the meanings of the scales were understood as From 1 to $1.8=$ Never; From 1.9 to $2.6=$ Seldom; From 2.7 to $3.4=$ Sometimes; From 3.5 to $4.2=$ Often; From 4.3 to $5=$ always. The SPSS for Windows 16.0 was used to analyze the data collected by Percent, Frequencies, Mean, Std. Deviation, T-Test, Spearman Correlation with confidence interval percentage at $95 \%$.

\section{Research Results}

\subsection{The Occurrence of Pedagogical Students' Misbehaviors}

Surveying the occurrence of pedagogical students' misbehaviors in Can Tho University in Vietnam, the results are shown in Table 1.

The data shown in Table 1 indicates that the mean of misbehaviors of pedagogical students is 2,055 which corresponds to a seldom level in the scale. The mean varies from 1.3621 to 2.7328 . The highest indicators, from the highest to the lowest, are as below: Using the cell phone without lecturer's permission in the classroom $(\mathrm{M}=2.7328$, $\mathrm{SD}=.74273$ ); Talking privately, making noise in the classroom ( $\mathrm{M}=2.4353, \mathrm{SD}=.72384)$; Working separately, not paying attention to lessons in the classroom $(\mathrm{M}=2.3103$, $\mathrm{SD}=.76065)$; Being late for school $(\mathrm{M}=2.2328$, $\mathrm{SD}=1.03076) ; \quad$ Plagiarism $\quad(\mathrm{M}=2.0733, \quad \mathrm{SD}=.84196)$; Falling asleep in the classroom $(\mathrm{M}=1.8190, \mathrm{SD}=.83328)$; Not following the request of the teacher in the classroom $(\mathrm{M}=1.4741, \mathrm{SD}=.62365)$; Putting rubbish indiscriminately in the classroom $(\mathrm{M}=1.4741, \mathrm{SD}=.62365)$. However, in terms of percentage, it is obvious that there is a certain percentage of pedagogical students who sometimes or often or always express misbehaviors in the classroom. This means the misbehaviors of pedagogical students in the classroom is diverse. Therefore, the hypothesis $\mathrm{H}_{01}$ is rejected.

Table 1. The occurrence of pedagogical students' misbehaviors

\begin{tabular}{|c|c|c|c|c|c|c|c|c|c|c|}
\hline \multirow{2}{*}{ No. } & \multirow{2}{*}{\multicolumn{2}{|c|}{ Misbehavior }} & \multicolumn{5}{|c|}{ Scale } & \multirow{2}{*}{ Mean } & \multirow{2}{*}{$\begin{array}{l}\text { Standard } \\
\text { deviation }\end{array}$} & \multirow{2}{*}{ Ranking } \\
\hline & & & 1 & 2 & 3 & 4 & 5 & & & \\
\hline \multirow{2}{*}{1} & \multirow{2}{*}{$\begin{array}{l}\text { Using the cell phone without } \\
\text { lecturer's permission in the } \\
\text { classroom }\end{array}$} & $\mathrm{F}$ & 12 & 64 & 133 & 20 & 3 & \multirow{2}{*}{2.7328} & \multirow{2}{*}{.74273} & \multirow{2}{*}{1} \\
\hline & & $\%$ & 5.2 & 27.6 & 57.3 & 8.6 & 1.3 & & & \\
\hline \multirow{2}{*}{2} & \multirow{2}{*}{$\begin{array}{l}\text { Talking privately, making noise in } \\
\text { the classroom }\end{array}$} & $\mathrm{F}$ & 24 & 91 & 109 & 8 & 0 & \multirow{2}{*}{2.4353} & \multirow{2}{*}{.72384} & \multirow{2}{*}{2} \\
\hline & & $\%$ & 10.3 & 39.2 & 47.0 & 3.4 & 0 & & & \\
\hline \multirow{2}{*}{3} & \multirow{2}{*}{$\begin{array}{l}\text { Working separately, not paying } \\
\text { attention to lessons in the } \\
\text { classroom }\end{array}$} & $\mathrm{F}$ & 34 & 99 & 93 & 5 & 1 & \multirow{2}{*}{2.3103} & \multirow{2}{*}{.76065} & \multirow{2}{*}{3} \\
\hline & & $\%$ & 14.7 & 42.7 & 40.1 & 2.2 & .4 & & & \\
\hline \multirow{2}{*}{4} & \multirow{2}{*}{$\begin{array}{l}\text { Putting rubbish indiscriminately } \\
\text { in the classroom }\end{array}$} & $\mathrm{F}$ & 158 & 66 & 7 & 0 & 1 & \multirow{2}{*}{1.3621} & \multirow{2}{*}{.58697} & \multirow{2}{*}{8} \\
\hline & & $\%$ & 68.1 & 28.4 & 3.0 & 0 & .4 & & & \\
\hline \multirow{2}{*}{5} & \multirow{2}{*}{ Plagiarism } & $\mathrm{F}$ & 60 & 105 & 61 & 2 & 4 & \multirow{2}{*}{2.0733} & \multirow{2}{*}{.84196} & \multirow{2}{*}{5} \\
\hline & & $\%$ & 25.9 & 45.3 & 26.3 & .9 & 1.7 & & & \\
\hline \multirow{2}{*}{6} & \multirow{2}{*}{ Being late for school } & $\mathrm{F}$ & 59 & 96 & 96 & 22 & 7 & \multirow{2}{*}{2.2328} & & \\
\hline & & $\%$ & 25.4 & 41.4 & 41.4 & 9.5 & 3.0 & & $1.050 / 0$ & 4 \\
\hline & Not following the request of the & $\mathrm{F}$ & 138 & 78 & 16 & 0 & 0 & 1741 & 60265 & \\
\hline 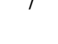 & teacher in the classroom & $\%$ & 59.5 & 33.6 & 6.9 & 0 & 0 & $1.4 / 41$ & . & 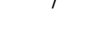 \\
\hline & & $\mathrm{F}$ & 94 & 94 & 39 & 2 & 3 & & & \\
\hline 8 & Falling asleep in the classroom & $\%$ & 40.5 & 40.5 & 16.8 & .9 & 1.3 & 1.8190 & .83328 & 6 \\
\hline & & Tot & & & & & & 2.0550 & .46372 & \\
\hline
\end{tabular}




\subsection{The Occurrence of Misbehaviors among Pedagogical Students Related to Their Gender, Majors, and School Year Status}

Surveying the occurrence of misbehaviors among pedagogical students in Can Tho University, Viet Nam related to their gender, majors, and school year status, the results are shown in Table 2.

Table 2. The correlation and differences in the mean score of misbehaviors of pedagogical students in terms of female and male, and school year

\begin{tabular}{|c|c|c|c|c|c|c|c|}
\hline \multirow[b]{2}{*}{ No. } & \multirow{2}{*}{\multicolumn{2}{|c|}{ Factors }} & \multirow[b]{2}{*}{ Mean } & \multicolumn{2}{|r|}{ Sig. } & \multirow{2}{*}{$\begin{array}{l}\text { Total } \\
\text { mean }\end{array}$} & \multirow{2}{*}{$\begin{array}{c}\text { Standard } \\
\text { Deviation }\end{array}$} \\
\hline & & & & \begin{tabular}{|c|} 
T- \\
Test \\
\end{tabular} & $\begin{array}{l}\text { Spearman } \\
\text { correlation }\end{array}$ & & \\
\hline \multirow{2}{*}{1} & \multirow{2}{*}{ Genders } & Male & 2.1118 & \multirow{2}{*}{.193} & \multirow{2}{*}{.197} & \multirow{7}{*}{2.0550} & \multirow{7}{*}{.46372} \\
\hline & & Female & 2.0272 & & & & \\
\hline \multirow{3}{*}{2} & \multirow{3}{*}{ Majors } & $\begin{array}{l}\text { Natural } \\
\text { science }\end{array}$ & 2.1528 & \multirow{3}{*}{.003} & \multirow{3}{*}{.006} & & \\
\hline & & & & & & & \\
\hline & & $\begin{array}{c}\text { Social } \\
\text { science }\end{array}$ & 1.9698 & & & & \\
\hline \multirow{2}{*}{3} & \multirow{2}{*}{ School year } & 2 nd year & 2.3333 & \multirow{2}{*}{.846} & \multirow[t]{2}{*}{.459} & & \\
\hline & & 3rd year & 2.4091 & & & & \\
\hline
\end{tabular}

- The correlation and differences in the mean score of misbehaviors of pedagogical students in terms of female and male:

The results based on T-Test and Spearman Correlation demonstrated in table 2 illustrates that sig. $>0,05$, which indicates that there are no statistical differences in the mean score of misbehaviors of pedagogical students between females and males. The mean of the score of misbehaviors of male pedagogical students is 2.1118 whereas that of the female pedagogical students is 2.0272. The difference is 0.0846. Male pedagogical students' mean score of misbehaviors is higher than female pedagogical students' but this difference is not significant. And it also shows that there is not a correlation at the level of misbehaviors of pedagogical students between females and males. Therefore, the hypothesis of $\mathrm{H}_{02}$ is accepted.

- The correlation and differences in the mean score of misbehaviors of pedagogical students in terms of natural science and social science:

The results based on T-Test and Spearman Correlation shown in table 2 illustrates total that sig. $<0,05$, which indicates that there are statistical differences in the mean score of misbehaviors of pedagogical students between natural science and social science. The mean of pedagogical students who major in social science's misbehaviors is 1,9698 and that of their natural science counterparts is 2,1528 . The difference rate is 0,183 which implied a statistical meaning. And it also shows that there is a correlation at the level of misbehaviors of pedagogical students between natural science and social science. Therefore, the hypothesis $\mathrm{H}_{03}$ is rejected.
- $\quad$ The correlation and differences in the mean score of misbehaviors of pedagogical students in terms of $2 \mathrm{nd}$ year and 3rd year:

The results based on T-Test and Spearman Correlation demonstrated in table 2 illustrates that sig. $>0,05$, which indicates that there are no statistical differences in the mean score of misbehaviors of pedagogical students between the 2nd- year and 3rd -year. The mean of the score of misbehaviors of 3rd year pedagogical students is 2.4091 whereas that of the 2nd -year pedagogical students is 2.3333 . The difference is 0.0758. 3rd-year pedagogical students's mean score of misbehaviors is higher than 2nd year pedagogical students' but this difference is not significant. And it also shows that there is not a correlation at the level of misbehaviors of pedagogical students between 2nd-year and 3rd-year. Therefore, the hypothesis of $\mathrm{H}_{04}$ is accepted.

\section{Discussion}

The previous studies discovered factors which relate to misbehavior including generation immigrants (Ewert. S, 2009), teacher (Karen Aldrupa et al, 2018; Gülay Dalgıç \& Güzide Bayhan, 2014; Martin et al,. 1999; Xinrui Yuan, 2012; Lewis, Romi, Qui \& Katz, 2005; Ariel M. Aloeet et al, 2014); classroom (Rachel C. F. Sun \& Daniel T. L. Shek, 2012), parents (Hoshiar Sadiq Sangawi et al, 2015), time, job, stress, efficacy, burnout (Little, 2005), cultural and educational contexts (Abbas Türnüklü \& Maurice Galton, 2001), students, society (Xinrui Yuan, 2012).

This study finds out the pedagogical students have various misbehaviors in the classroom including Talking privately, making noise in the classroom; Working separately, not paying attention to lessons in the classroom; Putting rubbish indiscriminately in the classroom; Plagiarism; Being late for school; Not following the request of the teacher in the classroom; Falling asleep in the classroom. These behaviors are not suitable for the school environment and for the personality of pedagogical students who will be teachers in the future. In terms of the mean score, the mean of misbehaviors of pedagogical students in the classroom is 2,055 which correspond to a seldom level in the scale. However, in terms of percentage, it is obvious that there is a certain percentage of pedagogical students who sometimes or often or always express misbehaviors in the classroom. Although these percentages are not high, it is worth attention, and finding appropriate measures to prevent these behaviors is very necessary. Because they not only negatively affect pedagogical students' personality but also negatively affect the teaching and learning process. Or it is possible to study the seven effective strategic applications of Rachel C. F. Sun (2014) including rules-setting, hinting, directive statements, punishment, after class talks, relationship building and instructional engagement to control student behavior while nurturing students' responsibility for managing one's behavior. In terms of majors, there is a 
statistical difference in the mean score of misbehaviors of pedagogical students between natural science and social science. The mean score of misbehaviors of pedagogical students who major in natural science is higher than pedagogical students who major in social science. And it also shows that there is a correlation at the level of misbehaviors of pedagogical students between natural science and social science. Therefore, the strong and close correlations between majored in natural science and social science are identified. The pedagogical students in different majors have a level of different misbehaviors which is worth considering in education. The cause of this difference is that the problem has not been identified and needs to be studied in the future. In terms of gender and school level, there are no statistical differences in the mean score of misbehaviors of pedagogical students between females and males, and between 2nd year and 3rd year. And it also shows that there is not a correlation at the level of misbehaviors of pedagogical students between females and males, and between 2 nd year and 3rd year. This reveals the fact that gender and school year do not impact on misbehaviors of pedagogical students and there are no correlations between female and male, between 2nd year and 3rd year for misbehaviors of pedagogical students. Although these differences are not significant they are worth the attention. Especially for the school year which pedagogical students attend? Because it seems that the higher the school year pedagogical students are in, the more misbehavior they express in the classroom. In this study, when compared to gender, majors and school year appear to be a stronger indicator for the level of misbehaviors conducted in the classroom among pedagogical students.

Thus, previous studies found out generation immigrants, teacher, classroom, time, job, stress, efficacy, burnout, cultural, educational contexts, students, society relate to misbehavior while this study finds out majors relate to misbehavior of pedagogical students. These findings help to put forward a suggestion that those who work in training and education need to pay attention to the characteristics of students' majors in the process of adjusting misbehaviors for students in the university.

\section{Conclusions}

The findings of the study indicate that pedagogical students have a variety of misbehaviors in the classroom including talking privately, making noise in the classroom; Working separately, not paying attention to lessons in the classroom; Putting rubbish indiscriminately in the classroom; Plagiarism; Being late for school; Not following the request of the teacher in the classroom; Falling asleep in the classroom. No correlation and significant differences between the mean score of misbehaviors of pedagogical students in terms of gender and school year are found. However, the correlation and significant differences between the mean score of misbehaviors of pedagogical students in terms of majors are identified. Majors are more likely to indicate the level of misbehaviors conducted in the classroom among pedagogical students better than gender. Therefore, it is necessary to find out the causes and solutions to preventing these misbehaviors of pedagogical students in the classroom within the teaching process for the next studies. It is recommended that remedies to the situation of pedagogical students' misbehaviors in the classroom should consider the distinction between their majors (natural science or social science) and adapt to them accordingly.

\section{Acknowledgments}

This research is funded by Can Tho University under grant number T2019-90

\section{REFERENCES}

[1] Alex Hwung. (2016). Peer Misbehavior Effects in the Classroom, CMC Senior Theses. Paper 1345

[2] Alice M. Buchanan, Vanessa Hinton. (2018). Positive Behavior Support in Physical Education: A Case from a Pre-service Field Experience. International Journal of Learning, Teaching and Educational Research, Vol. 17, No. 2, pp. 74-86. https://doi.org/10.26803/ijlter.17.2.5

[3] Andrew j. martin, Ken Linfoot, and Jennifer Stephenson. (1999). How to teachers respond to concerns about misbehavior in their classroom. Psychology in the Schools, v36 n4, 347-58 Jul.

https://doi.org/10.1002/(SICI)1520-6807(199907)36:4<347 ::AID-PITS7>3.0.CO;2-G

[4] Ariel M. Aloe, Shannon M. Shisler, Benjamin D. Norris, Amanda B. Nickerson, Tyler W. Rinker. (2014). A multivariate meta-analysis of student misbehavior and teacher burnout. Educational Research Review 12, 30-44. https://doi.org/10.1016/j.edurev.2014.05.003

[5] Bru, E., Stephens, P., \& Torsheim, T. (2002). Students' perceptions of class management and reports of their own misbehavior. Journal of School Psychology, 40, 287-307. https://doi.org/10.1016/S0022-4405(02)00104-8

[6] Burke, R. J., Greenglass, E. R., \& Schwarzer, R. (1996). Predicting teacher burnout over time: Effects of work stress, social support, and self-doubts on burnout and its consequences. Anxiety, Stress and Coping, 9, 261-275. https://doi.org/10.1080/10615809608249406

[7] Ewert. S. (20009). Student misbehavior during senior year: A comparison of immigrants and the native-born. Social Science Research. Volume 38, Issue 4, 826-839. DOI:10.1016/j.ssresearch.2009.04.004.

[8] Fernet, C., Guay, F., Senecal, C., \& Austin, S. (2011). 
Predicting intraindividual changes in teacher burnout: The role of perceived school environment and motivational factors. Teaching and Teacher Education: An International Journal of Research and Studies, 28(4), 514-525. doi:10.1016/j.tate.2011.11.013

[9] Finn, J. D., Fish, R. M., \& Scott, L. A. (2008). Educational sequelae of high school misbehavior. Journal of Educational Research, 101, 259-274.

https://doi.org/10.3200/JOER.101.5.259-274

[10] Friedman, I. A. (1995). Student behavior patterns contributing to teacher burnout. The Journal of Educational Research, 88, 281-289

https://doi.org/10.1080/00220671.1995.9941312

[11] Gülay Dalgıç \& Güzide Bayhan. (2014). A Meta-Analysis: Student Misbehaviors That Affect Classroom Management. Cypriot Journal of Educational Sciences, Volume 9, Issue 2, 101-116.

[12] https://www.academia.edu/35534894/A_Meta-Analysis_St udent_Misbehaviors_That_Affect_Classroom_Management

[13] Houghton, S., Wheldall, K., \& Merrett, F. (1988). Classroom behaviour problems which secondary school teachers say they find most troublesome. British Educational Research Journal, 14(3), 297-312.

https://doi.org/10.1080/0141192880140306

[14] Hoshiar Sadiq Sangawi, John Adams\& Nadja Reissland. (2015). The Effects of Parenting Styles on Behavioral Problems in Primary School Children: A Cross-Cultural Review. Asian Social Science; Vol. 11, No. 22; 2015, 171-186. DOI: $10.5539 /$ ass.v1 $1 \mathrm{n} 22 \mathrm{p} 171$

[15] James T. Croasmun \& Lee Ostrom. (2011). Using Likert-type Scales in the Social Sciences, Journal of Adult Education, Volume 40, Number 1. https://files.eric.ed.gov/fulltext/EJ961998.pdf

[16] Karen Aldrupa, Uta Klusmanna, Oliver Lüdtkea,b, Richard Göllnerc,d, Ulrich Trautweind. (2018). Student misbehavior and teacher well-being: Testing the mediating role of the teacher-student relationship, Learning and Instruction 58, 126-136

[17] Kyriacou, C. (1997). Effective Teaching in School. (2nd ed.). Cheltenham: Nelson Thornes, 121

[18] Lewis, R., Romi, S., Xing, Q., \& Katz, Y. (2005). Teachers' classroom discipline and student misbehavior in Australia, China, and Israel. Teaching and Teacher Education, 21, 729-741. DOI: 10.1016/j.tate.2005.05.008

[19] Li Li \& Scott Titsworth. (2015). Student Misbehaviors in Online Classrooms: Scale Development and Validation. The American Journal of Distance Education, 29:41-55, 2015. https://doi.org/10.1080/08923647.2015.994360

[20] Little E. (2005). Secondary school teachers' perceptions of students' problem behaviors. Education Psychology, 25 (4),
369-377. https://doi.org/10.1080/01443410500041516

[21] Long, M. (2000). The Psychology of Education. London: Routledge Falmer. Chapters 10 and 11

[22] McCormick, J., \& Barnett, K. (2011). Teachers' attributions for stress and their relationships with burnout. International Journal of Educational Management, 25(3), 278-293. https://doi.org/10.1108/09513541111120114

[23] Rachel C. F. Sun \& Daniel T.L.Shek. (2012). Student Classroom Misbehavior: An Exploratory Study Based on Teachers' Perceptions. The Scientific World Journal, Article ID 208907, 8 pages. https://doi.org/10.1100/2012/208907

[24] Rachel C. F. Sun \& Daniel T. L. Shek. (2012). Classroom Misbehavior in the Eyes of Students: A Qualitative Study. Scientific World Journal, Volume 2012, Article ID 398482, 8 pages. https://doi.org/10.1100/2012/398482

[25] Rachel C.F. Sun. (2014). Teachers' experiences of effective strategies for managing classroom misbehavior in Hong Kong. Journal of Teaching and teacher education 46, 94-103. https://doi.org/10.1016/j.tate.2014.11.005

[26] Robers, S., Zhang, J., Truman, J., \& Snyder, T. D. (2012). Indicators of school crime and safety: 2011 (NCES 2012-002/NCJ 236021). National Center for Education Statistics, U.S. Department of Education, and Bureau of Justice Statistics, Office of Justice Programs, U.S. Department of Justice. Washington, DC

[27] Thompson B. (2009). Disruptive behavior in Barbadian classrooms: implications for universal secondary education in the Caribbean. Journal of Eastern Caribean Studies, 34 (3), 39-58

[28] DG. N. Tiwari \& Heena Panwar. (2014). A study on the management of classroom behavior problems at the secondary level. American research thoughts - Volume 11, Issue 1. Available online at www.researchthoughts.us

[29] Turnuklu, A., \& Galton, M. (2001). Students' misbehaviors in Turkish and English primary classrooms. Educational Studies, 27(3), 291-305. $10.1080 / 03055690120076574$

[30] Van Dat Tran. (2016). Coping Styles with Student Misbehavior as Mediators of Teachers' Classroom Management Strategies. International Journal of Higher Education, Vol. 5, No. 1. DOI: 10.5430/ijhe.v5n1p1

[31] Wheldall, K. (1991). Managing troublesome classroom behavior in regular schools: A Positive Teaching perspective. International Journal of Disability, Development, and Education, 38, 99-116. https://doi.org/10.1080/0156655910380202

[32] Xinrui Yuan. (2012). How to Deal with Student Misbehaviour in the Classroom? Journal of Educational and Developmental Psychology, Vol. 2, No. 1; May, 143-149. DOI:10.5539/jedp.v2n1p143 